\title{
Empirical Study of Foreign Exchange Remittance of Non-Resident Indians
}

\author{
Babasaheb Jadhav', Rucha Tandulwadkar ${ }^{2} \&$ Vidya $^{3}$ \\ ${ }^{1}$ Associate Professor, Dr. D. Y. Patil Vidyapeeth's, Global Business School and Research Centre, Pune, \\ Maharashtra, India \\ ${ }^{2}$ Associate Professor, BPHE Society's, Institute of Management Studies, Career Development and Research, \\ Ahmednagar, Maharashtra, India \\ ${ }^{3}$ Assistant Professor, Shri. H. D. Devegowda Government First Grade College, Paduvalahippe, Karnataka, India
}

Article History: Received: 10 November 2020; Revised: 12 January 2021; Accepted: 27 January 2021;

Published online: 05 April 2021

\begin{abstract}
Remittances sent by migrants are an important component of the development finance for the countries. India has secured position as the world's top beneficiary of remittances with USD 80 million in 2018. The study was done in the Maharashtra State which leads the number in remittance (17\%). The study highlighted the foreign exchange remittance behaviour of NRIs. The present study tried to understand the remittance behaviour of NRIs and remittance behaviour with respect to demographic profile. The remittance behaviour is studied with the help of demographic and non-demographic factors such as gender, age, occupation, education, purpose of remittance, frequency of remittance, risk in remittance etc.
\end{abstract}

Keywords: Foreign Exchange, Remittances, Remittance Behaviour, Demographic Profile, Growth \& Development etc

\section{Introduction}

Monetary remittances by migrants constitute a behavior of significant economic importance. Remittances sent by migrants are an important component of the finance for the countries. Remittances are an important source of external finance for the growth and development of any country. Evidence is there to establish the fact that remittances help in reducing poverty and children's education. The transfer of funds can be used for consumption, savings, investment purposes, housing expenses and healthcare. Contribution by remittances made by Indians living abroad and classified as NRIs are no different. Remittances by Indian migrants have been increasing over the years. India has registered a significant growth in remittances from USD 63 Million in 2016 to USD 80 Million in 2018. A major chunk of NRI population of India is Kerala, Maharashtra \& Karnataka, who contribute more than $50 \%$ of the economic output of the state $\&$ thereby participate in the growth of India.

This study explores the frequency of remittance with regard to certain demographic variables like gender, age, education etc. which could be of interest to policymakers who can study it as a major development issue.

\section{Literature Review}

Zachariah \& Rajan (2015) Remittance behaviour was studied through factors like age, education, duration of stay, wages, migrant status, working conditions, motive for remitting, size of household etc.

It is imperative to understand the remittance behavior also because the purpose of remittances affects the end uses of such funds.

Stark and Bloom (1985), this study considers migration enhances income levels, investment capacity and acquires insurance against risk. The major findings of this study was that remittance is used for household's development.

Vanwey (2004) this study found more tendency to remit for women than men. The purpose of remittance was family growth, investments, education and medical emergency.

Rajan (2011) observed from the study that the remittance sending is more likely male dominating. The purpose of remittance was investments and education.

De la Briere et al. (2002) analysis reveals remittance behavior varies with gender and household composition. It is observed from the study that the remittance sent by male is more than the female.

Osili (2007) study has shown that remittances are significantly associated with household size, education, health conditions and operational risk.

There are very few studies available in the Indian context and hardly any in the context of Maharashtra which 
gets the most of the remittance inflows which makes it a good case for the researchers to undertake this study.

\section{Methodology, Research Area \& Sampling Design}

\subsection{Topic of the Research}

Empirical Study of Foreign Exchange Remittance of Non-Resident Indians

\subsection{Objective of the Research}

1. To study the foreign exchange remittances of Non-Resident Indians.

2. To study the variance in remittance behaviour with respect to demographic variables by considering factors like purpose, frequency and risk of remittance as various behavioral perspectives.

\subsection{Scope of the Research}

The scope of the study was limited to State of Maharashtra \& NRI only

\subsection{Hypothesis of the Research}

Ho: There is significant relationship between gender, age, occupation and education \& frequency of remittance

H1: $_{1}$ There is no significant relationship between gender, age, occupation and education \& frequency of remittance

\subsection{Research Design of the Research}

The research design of the present research was as follows:

\section{a) Types of Data}

A primary and secondary data was used for this research study. The primary data was a fresh data and secondary data was already exists in some or the other form and was collected already by someone else.

\section{b) Sources of Data}

The primary data was collected through structured questionnaire. The secondary data was collected from various Annual reports, Quarterly reports of the economy, Newspapers and Reference Books, Journals and Internet Media sources.

\section{c) Sample Size}

The sample size for present research study was 50 .

\section{d) Sampling Method}

Purposive sampling method was used to identify the respondents.

\section{e) Data Collection Method}

Structured questionnaire was used for data collection

\section{f) Tools for Data Presentation}

The tools such as tables \& line charts were used for data analysis and presentation.

\section{g) Statistical Tools for Hypothesis Testing}

The statistical tools such as trend analysis, Pearson correlation and standard deviation method were used for 
data analysis \& hypothesis testing.

\section{Result \& Discussion}

This section provides the results of analysis \& the discussion part. Table shows male respondents were more $(68 \%)$. Most of the respondents who are part of this study are professionals (48\%) \& majority are post graduates $(52 \%)$.

Table 1. Remittances to India in US\$ Million

\begin{tabular}{|l|l|}
\hline Years & Amount \\
\hline $2001-2002$ & 15400 \\
\hline $2002-2003$ & 16390 \\
\hline $2003-2004$ & 21610 \\
\hline $2004-2005$ & 20250 \\
\hline $2005-2006$ & 24550 \\
\hline $2006-2007$ & 29100 \\
\hline $2007-2008$ & 37200 \\
\hline $2008-2009$ & 51600 \\
\hline $2009-2010$ & 55060 \\
\hline $2011-2012$ & 66100 \\
\hline $2012-2013$ & 67600 \\
\hline $2013-2014$ & 70370 \\
\hline $2014-2015$ & 66300 \\
\hline $2015-2016$ & 62700 \\
\hline $2016-2017$ & 65300 \\
\hline $2017-2018$ & 80000 \\
\hline Source: Reserve Bank of India \\
\hline
\end{tabular}

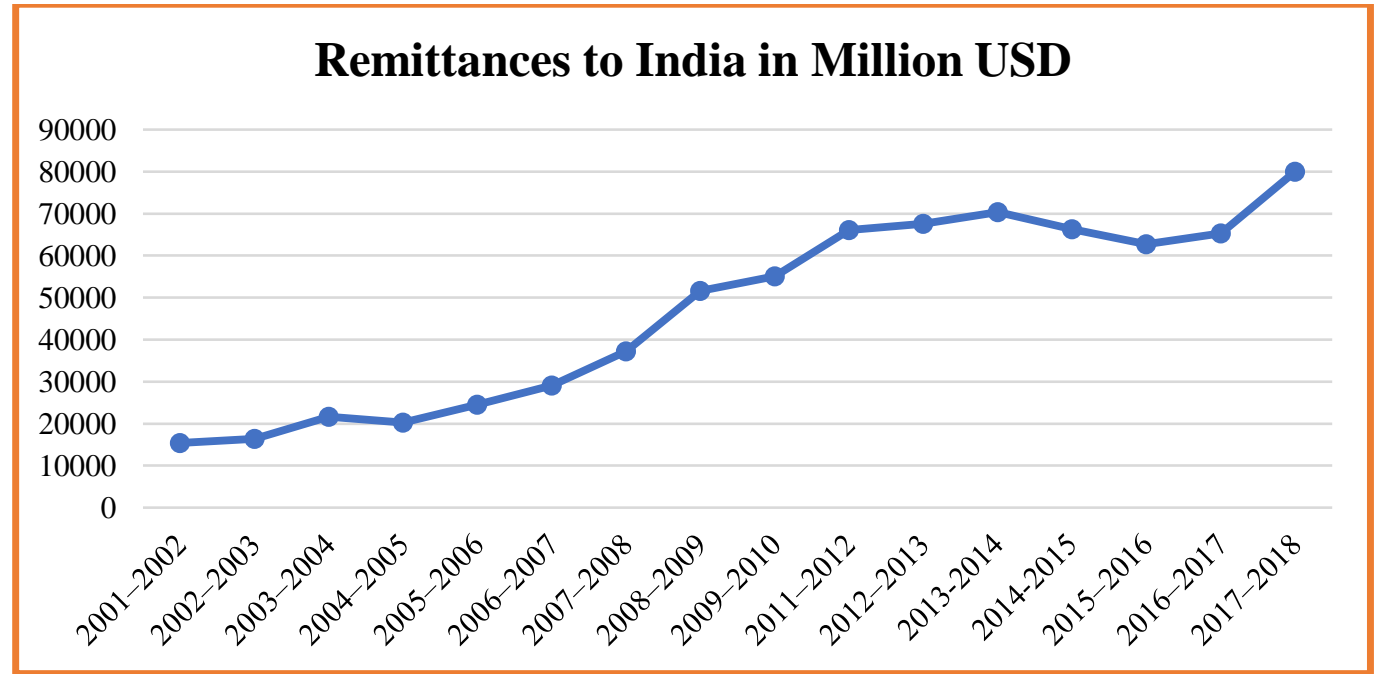

Table 2. Percentage Share of State wise Remittances in India

\begin{tabular}{|l|l|}
\hline States & Share in Percentage \\
\hline Kerala & 19 \\
\hline Maharashtra & 16.7 \\
\hline Karnataka & 15 \\
\hline Tamilnadu & 8 \\
\hline Delhi & 5.9 \\
\hline Andhra Pradesh & 4 \\
\hline Uttar Pradesh & 3.1 \\
\hline West Bengal & 2.7 \\
\hline Gujrat & 2.1 \\
\hline Punjab & 1.7 \\
\hline Others & 21.8 \\
\hline
\end{tabular}


Source: Reserve Bank of India

\section{Percentage Share in Statewise Remittances}

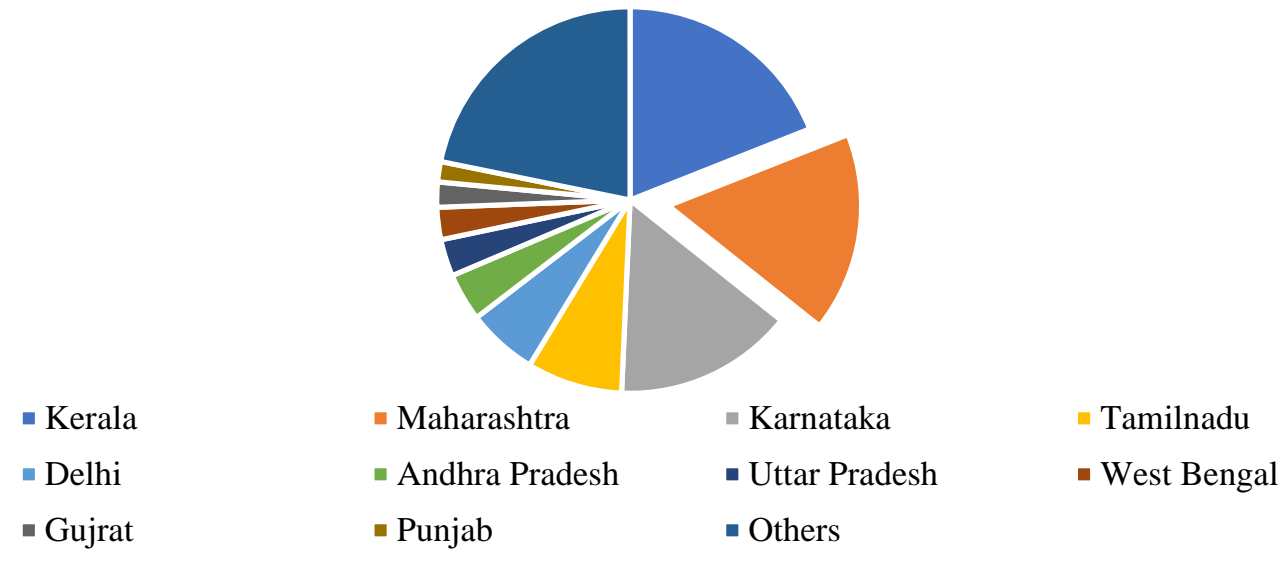

Table 3. Country-wise Remittances in Million USD

\begin{tabular}{|l|l|l|}
\hline Rank & Country & Amount \\
\hline 1 & UAE & 13823 \\
\hline 2 & United States & 11715 \\
\hline 3 & Saudi Arabia & 11239 \\
\hline 4 & Kuwait & 4587 \\
\hline 5 & Qatar & 4143 \\
\hline 6 & UK & 3941 \\
\hline 7 & Oman & 3250 \\
\hline 8 & Nepal & 3016 \\
\hline 9 & Canada & 2877 \\
\hline 10 & Australia & 1944 \\
\hline \multicolumn{2}{|l|}{ Source: Reserve Bank of India } \\
\hline
\end{tabular}

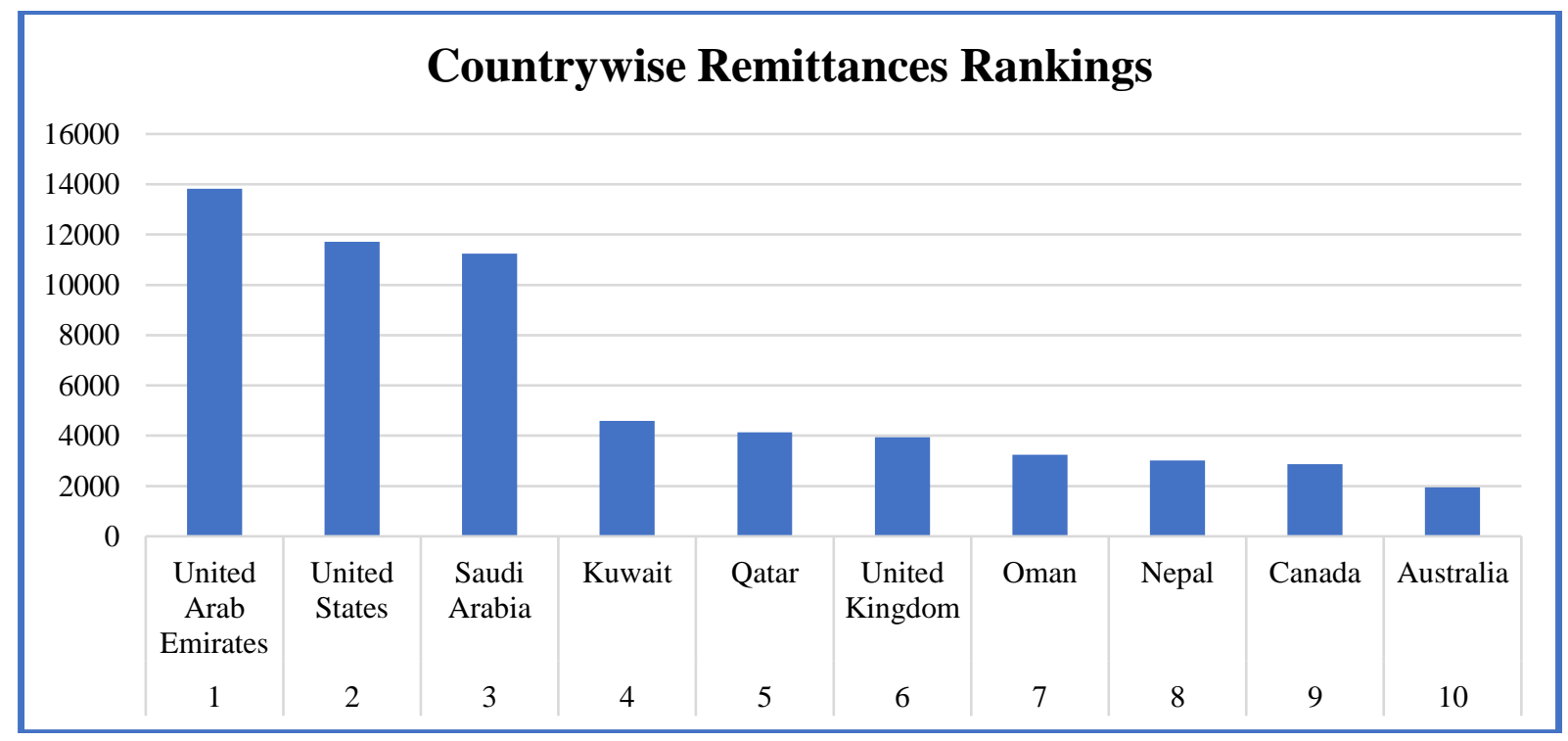

Table 4. Profile of Respondents

\begin{tabular}{|l|l|l|l|}
\hline Characteristics of Surveyed Data $(\mathbf{N}=50)$ & \multicolumn{3}{l|}{} \\
\hline Demographic Variable & Item & Count & Percentage \\
\hline \multirow{3}{*}{ Gender } & Male & 34 & 68 \\
\cline { 2 - 5 } & Female & 16 & 32 \\
\hline
\end{tabular}




\begin{tabular}{|l|l|l|l|}
\cline { 2 - 4 } Age & Total & 50 & 100 \\
\hline & $20-30$ & 5 & 10 \\
\cline { 2 - 4 } & $31-40$ & 19 & 38 \\
\hline $41-50$ & 21 & 42 \\
\hline \multirow{5}{*}{ Occupation } & $51-60$ & 5 & 10 \\
\hline & Total & 50 & 100 \\
\hline \multirow{5}{*}{ Education } & Business & 11 & 22 \\
\cline { 2 - 4 } & Professional & 24 & 48 \\
\hline & Government Staff & 4 & 8 \\
\cline { 2 - 4 } & Others & 11 & 22 \\
\hline & Total & 50 & 100 \\
\hline & Higher Secondary & 0 & 0 \\
\hline & Graduate & 18 & 36 \\
\hline & Post Graduate & 26 & 52 \\
\hline & Others & 6 & 12 \\
\hline & Total & 50 & 100 \\
\hline
\end{tabular}

With regard to frequency of remittance, it is observed that the majority of the respondents (46) prefer to remit monthly rather than weekly, quarterly, half yearly or yearly.

Table 5. Frequency of Remittance

\begin{tabular}{|l|l|l|l|l|}
\hline Period & Frequency & \% & Valid \% & Cumulative \% \\
\hline Weekly & 4 & 8 & 8 & 8 \\
\hline Monthly & 23 & 46 & 46 & 54 \\
\hline Quarterly & 14 & 28 & 28 & 82 \\
\hline Half Yearly & 6 & 12 & 12 & 94 \\
\hline Yearly & 3 & 6 & 6 & 100 \\
\hline Total & 50 & 100 & 100 & \\
\hline
\end{tabular}

Table 6. Importance of Risk while remitting

\begin{tabular}{|l|l|l|l|l|}
\hline Risk while remitting & N & Maximum & Mean & Std. Deviation \\
\hline Operational Risk & 50 & 4.00 & 2.2609 & 0.80423 \\
\hline Interest Rate Risk & 50 & 4.00 & 2.2609 & 0.85695 \\
\hline Transaction Risk & 50 & 4.00 & 2.2754 & 0.87769 \\
\hline Exchange Risk & 50 & 4.00 & 2.2754 & 0.88597 \\
\hline
\end{tabular}

When respondents were asked about the main risk factor which they consider while remitting among Operational Risk, Interest Rate Risk, Transaction Risk \& Exchange Risk it was observed that operational risk is considered as the main risk factor while remitting money. Table shows that as the mean is high and the standard deviation is low in the case of operational risk, it is inferred that operational risk is considered as the main risk factor while remitting money.

Table 7. Purpose of Remittance

\begin{tabular}{|l|l|l|l|l|}
\hline Purpose of Remittance & Frequency & $\%$ & Valid Percent & Cumulative \% \\
\hline Family Expenditure & 26 & 52 & 52 & 52 \\
\hline Investment in land \& property & 7 & 14 & 14 & 66 \\
\hline Investment in Equity shares & 2 & 4 & 4 & 70 \\
\hline Bank deposits & 11 & 22 & 22 & 92 \\
\hline Others & 4 & 8 & 8 & 100 \\
\hline Total & 50 & 100 & 100 & \\
\hline
\end{tabular}

The objective of the study was to find out the purpose of remittance by NRIs. From the study it was observed that the majority of the respondents remit money so as to help families to meet the expenditure. Results show $52 \%$ of the respondents remit money for family expenditure.

\section{Hypothesis framed for the Study}


There is significant relationship between gender, age, occupation and education \& frequency of remittance

Table 8. Gender \& Frequency of Remittance

\begin{tabular}{|l|l|l|l|}
\hline & Value & Df & Asymp. Sig. (2-sided) \\
\hline Pearson chi-square & $21.652 \mathrm{a}$ & 8 & 0.006 \\
\hline $\mathrm{N}$ & 50 & & \\
\hline
\end{tabular}

Result: The value of the test is 0.006 . It is below the critical value of 0.05 . There is a significant relationship between gender \& frequency of remittance. There by $\mathrm{H}_{0}$ is rejected.

Table 9. Age \& Frequency of Remittance

\begin{tabular}{|l|l|l|l|}
\hline & Value & Df & Asymp. Sig. (2-sided) \\
\hline Pearson chi-square & $30.808 \mathrm{a}$ & 16 & 0.014 \\
\hline $\mathrm{N}$ & 50 & & \\
\hline
\end{tabular}

Result: The value of the test is 0.014 . It is below the critical value of 0.05 . There is a significant relationship between age $\&$ frequency of remittance. There by $\mathrm{H}_{0}$ is rejected.

Table 10. Occupation \& Frequency of Remittance

\begin{tabular}{|l|l|l|l|}
\hline & Value & Df & Asymp. Sig. (2-sided) \\
\hline Pearson chi-square & $19.938 \mathrm{a}$ & 12 & 0.068 \\
\hline $\mathrm{N}$ & 50 & & \\
\hline
\end{tabular}

Result: The value of the test is 0.068 . It is above the critical value of 0.05 . There is no significant relationship between occupation \& frequency of remittance. So $\mathrm{H}_{0}$ is accepted.

Table 11. Education \& Frequency of Remittance

\begin{tabular}{|l|l|l|l|}
\hline & Value & Df & Asymp. Sig. (2-sided) \\
\hline Pearson chi-square & $15.751 \mathrm{a}$ & 12 & 0.203 \\
\hline $\mathrm{N}$ & 50 & & \\
\hline
\end{tabular}

Result: The value of the test is 0.203 . It is above the critical value of 0.05 . There is no significant relationship between education \& frequency of remittance. So $\mathrm{H}_{0}$ is accepted.

\section{Conclusion}

It was observed that gender wise variations have been observed in the context of remittance and the impact of education on remittances is mixed.

The researchers have tried to study the relationship between other demographic variables \& remittance behavior by introducing variables like age \& occupation and finally it can be concluded that gender $\&$ age have significant relationship with remittance. Education \& occupation have no significant relationship and this aspect needs to be explored further.

From this study, it is evident that the majority of the respondents remit money so as to help families to meet the expenditure.

With regard to frequency of remittance, it is observed that majority of the respondents prefer to remit monthly \& accessibility is the most important factor considered while choosing a remittance service provider followed by reliability \& operational risk is considered as the main risk factor by NRIs while remitting money.

Most preferred mode of transfer is through banks and second most preferred mode of transfer is online fund transfer, it is imperative that the service providers should locate their branches where there is more NRI and the operation procedures for transfer should be transparent.

The customers should be taken care of properly and they should be educated about the operational risks involved in the transactions. 


\section{References}

1. https://dbie.rbi.org.in/DBIE/dbie.rbi?site=statistics

2. https://tradingeconomics.com/india/remittances

3. Agarwal, R., \& Horowitz, A.W. (2002). Are international remittances altruism or insurance? Evidence from Guyana using multiple-migrant households. World Development, 30(11),20332044.

4. Holst, E., A. Schafer, and M. Schrooten (2010): "Gender, Transnational Networks and Remittances: Evidence from Germany," Discussion Papers of DIW Berlin 1005, DIW Berlin, German Institute for Economic Research.

5. Kapur, D. (2004), "Remittances: The New Development Mantra?" G-24 Discussion Paper Series No. 29 (New York and Geneva, UN Conference on Trade and Development, 2004).

6. Kugler, M. and Rapoport, H., 2007. International labor and capital flows: Complements or substitutes? Economics Letters, 94(2), pp.155-162.

7. Vanwey, L. 2004. Altruistic and Contractual Remittances between Male and Female Migrants and Households in Rural Thailand. Demography 41(4):739-56. 